\title{
Degraded agricultural terraces, landslides and gullies from Libertatea village
}

\author{
Mihai Niculiță, Mihai Ciprian Mărgărint \\ Department of Geography, Faculty of Geography and Geology \\ Alexandru Ioan Cuza University of Iaşi \\ Iaşi, Romania \\ mihai.niculita@uaic.ro,margarint.ciprian@yahoo.com
}

Terraced landscapes of Romania are the result of recent modifications of agricultural landscapes, being characterized mainly by agro-terraces (as land use) and earth terraces (as construction material) [1]. While some references of preroman (Cotofeni Culture - 3000 BP and Iron Age Dacia) and roman agricultural terraces are cited in the archaeological literature, the majority of the agricultural terraces of Romania were built during the Austro-Hungarian conquest of Transylvania in the 19th century or after the World Second War, during the communist regime (1960-1980). Nowadays the terracing is done on small areas in the same approach as during the communist regime [2].

The main purpose of the terraces was to create a flat surface were crops can be grown in good conditions, and to reduce the soil erosion, by decreasing the slope and the length of the hillslope. Water conservation was also targeted, the decrease of slope increasing the water retention in soils, on the terrace benches.

The 19th century terraces are mainly bench terraces, while the 20th century terraces are mainly broad-base terraces for hillslopes with slope under $15-20 \%$ and bench terraces for hillslopes over 15-20\%.

Degradation by the lack of maintenance and change of land use are one of the most important challenges regarding the terraced landscapes of Romania [3].

Soil erosion, landsliding and gullying will affect these lands, since the land use and the maintenance are the single measures that can reduce them (in the absence of stone walls and drainage systems).

The mapping of the terraced areas is a must in order to better assess the state of these lands and to be able to propose measures to reduce the degradation of soils and landscapes $[4,5]$.
The Chișcata upper catchment (locally known as Hârtopul Lupăriei) from the territory of Libertatea and Călărași villages is a representative area for the situation of Romanian abandoned terraced landscapes (Fig. 1), where soil erosion, gully erosion and landslides (Fig. 2, 3, 4) have a continuous dynamic.

\section{ACKNOWLEDGMENT}

We are grateful to Prut-Bârlad Water Administration who provided us with the LIDAR data. We have used the computational facilities given by the infrastructure provided through the POSCCE-O 2.2.1, SMIS-CSNR 13984-901, No. 257/28.09.2010 Project, CERNESIM (L4).

\section{REFERENCES}

[1] M. Niculiță, “Terraced landscapes of Romania”, $3^{\text {rd }}$ World Meeting on Terraced Landscapes, 6-15 October 2016, Venice-Padua.

[2] C.M. Mărgărint, M. Niculiță, and P. Tarolli, "Types and evolution stages of the agricultural terraces in the northern part of the Moldavian Plateau (NE Romania) based on their geomorphometric characteristics", $3^{\text {rd }}$ World Meeting on Terraced Landscapes, 6-15 October 2016, VenicePadua.

[3] C.M. Mărgărint, M. Santangelo, M. Niculiță, and F. Bucci, "Spatiotemporal relation between landslide occurrence and abandoned or not maintained agricultural terraces in the Moldavian Plateau, NE Romania”, Geophysical Research Abstracts, vol. 18, EGU2016-9495-1, 2016.

[4] P. Tarolli and G. Sofia, "Human topographic signatures and derived geomorphic processes across landscapes", Geomorphology, vol. 255, pp. 140-161, 2016.

[5] P. Tarolli, G. Sofia, S. Calligaro, M. Prosdocimi, F. Preti, and G. Dalla Fontana, "Vineyards in terraced landscapes: new opportunities from Lidar data”, Land Degradation and Development, vol. 26, no. 1, pp. 92102, 2015 


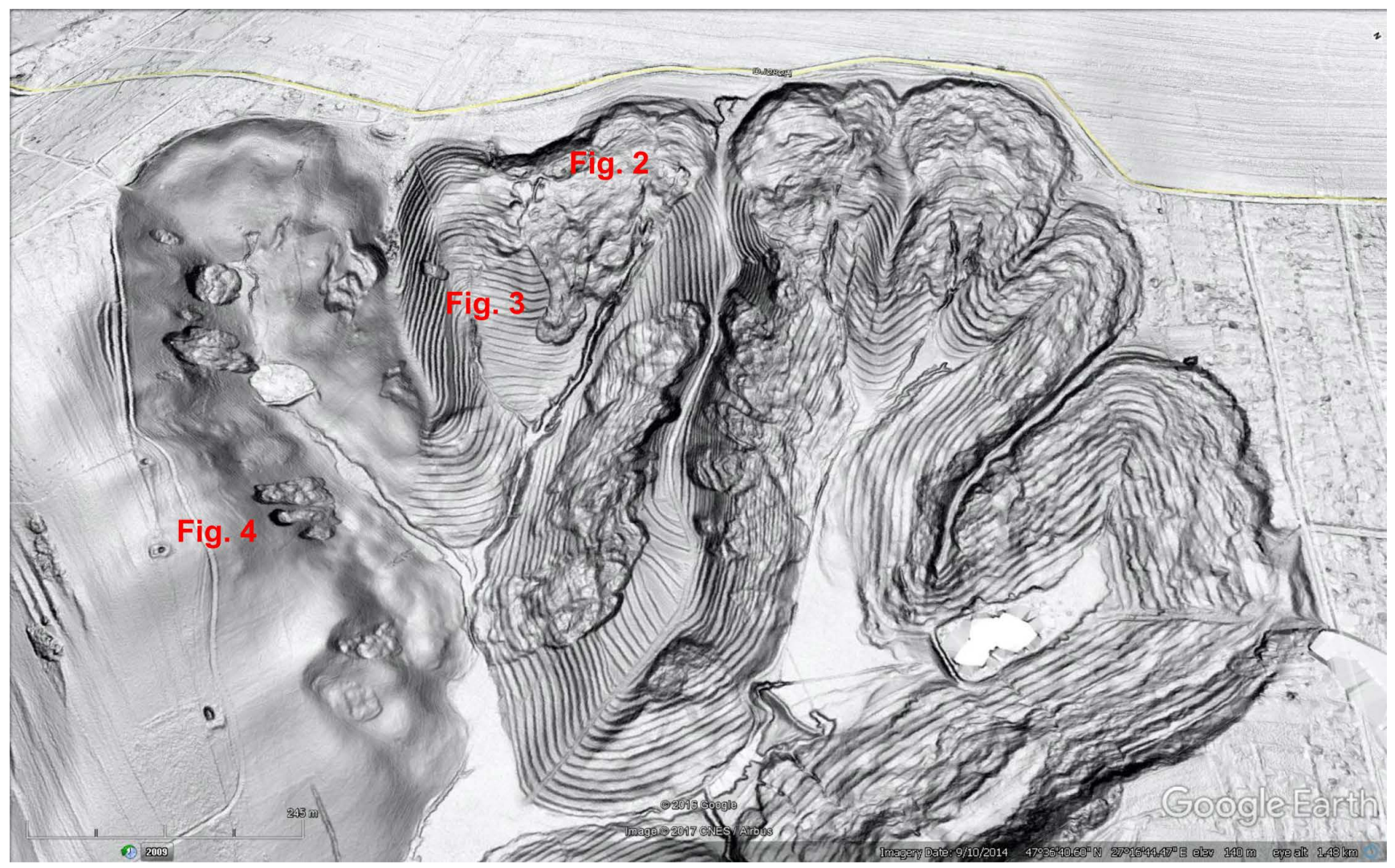

Fig. 1. The Lupăriei Hârtop from Libertatea and Călăraşi villages: shaded LiDAR view.

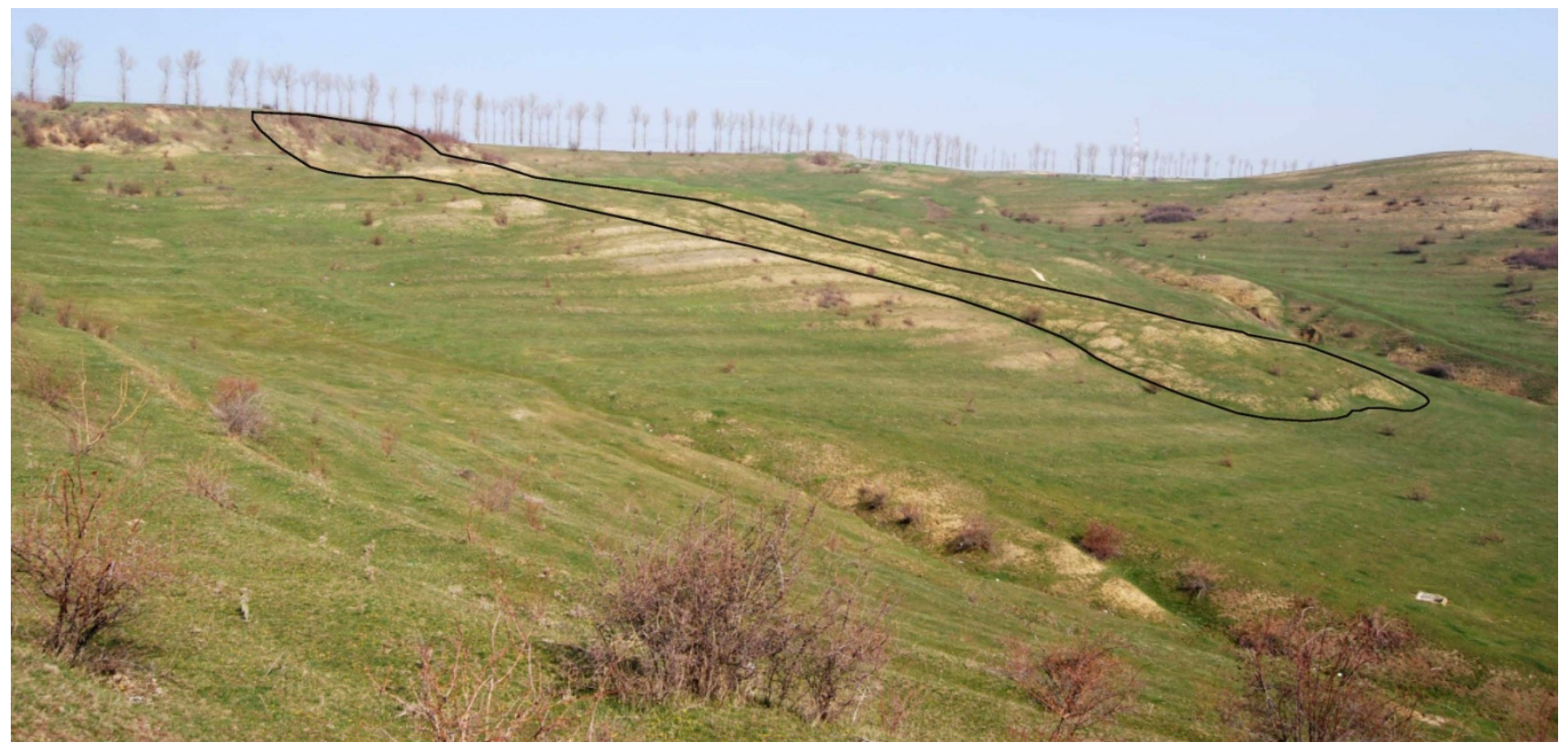

Fig. 2. A flow from the Lupăriei Hârtop. 


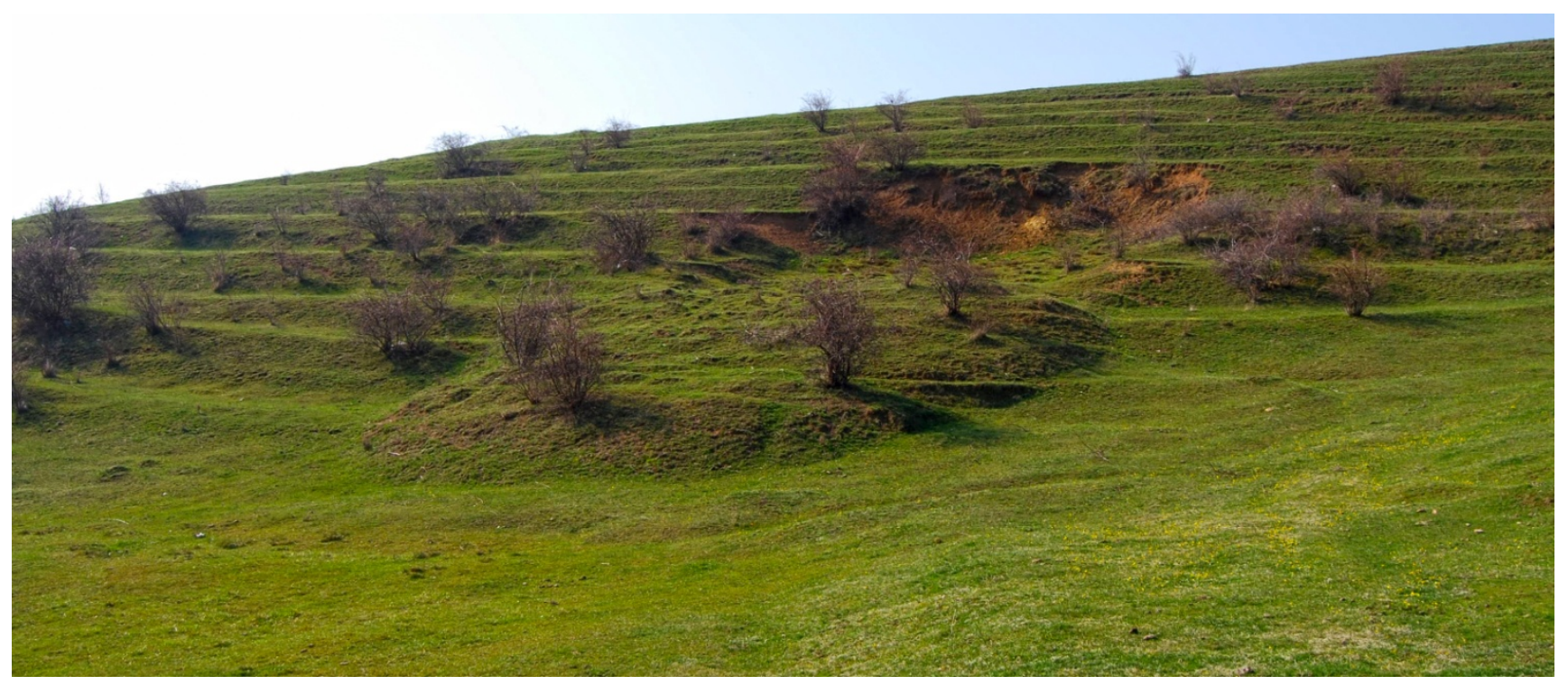

Fig. 3. A translational landslide from the Lupăriei Hârtop.

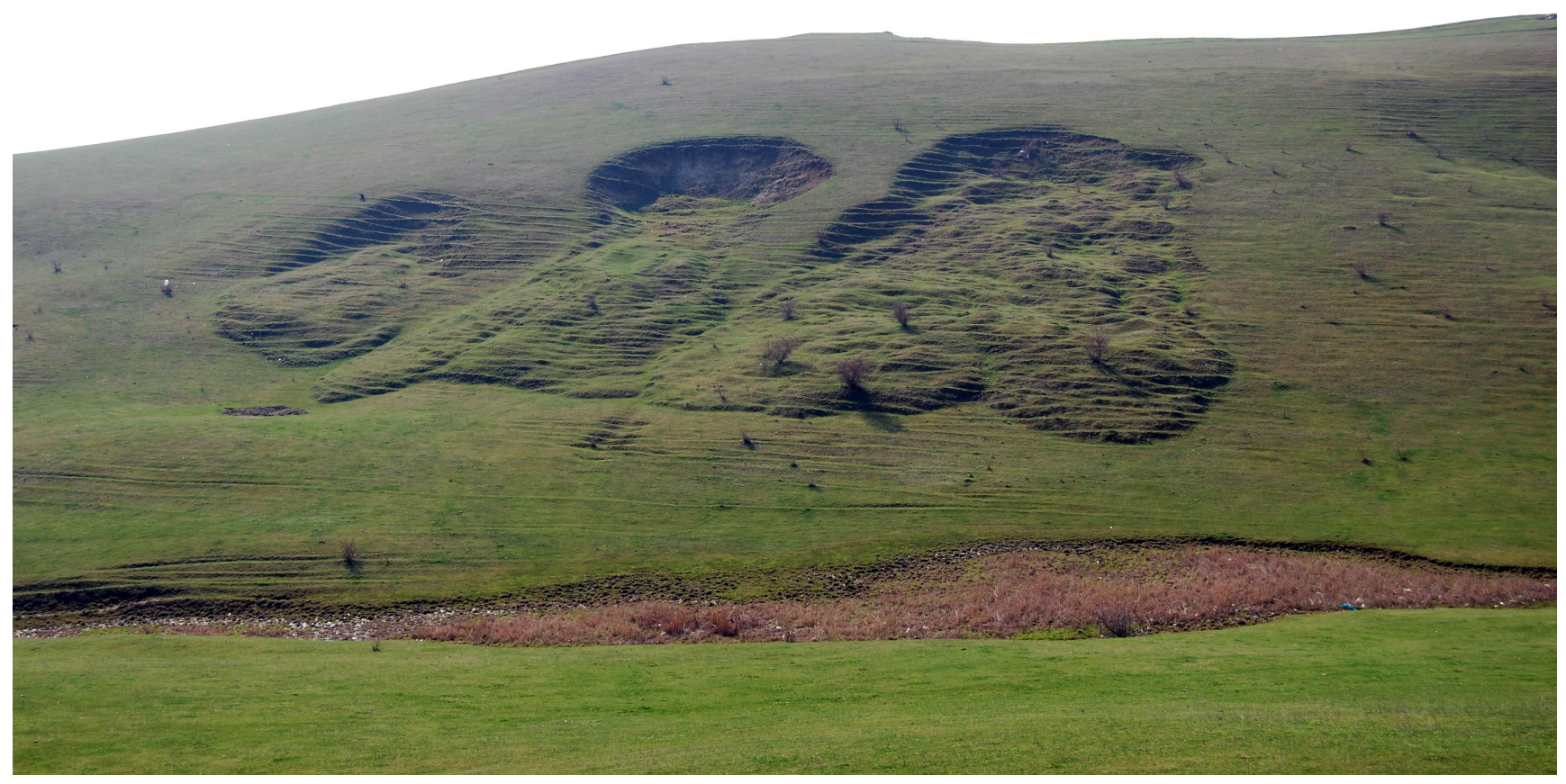

Fig. 4. Translational slides and flow-slides from the Lupăriei Hârtop. 